\title{
Developing L2 prosodic competence online: Implications of the emergency remote teaching
}

\author{
Tatiana Aleksandrovna Polushkina - Elena Genrikhovna Tareva
}

DOI: 10.18355/XL.2021.14.01.03

\begin{abstract}
This paper addresses the issue of transferring L2 prosody teaching to online settings due to the lockdown. The reasons are provided to account for the vulnerable status of pronunciation teaching and related risks. We report the results of the research project carried out in Moscow Institute of Physics and Technology with forty Russianspeaking engineering students. In this study a combination of qualitative and quantitative research methods was used. The study first provided a critique of preexisting computer-based pronunciation training (CAPT) options ensuring learning continuity. These options were then analyzed against global educational policies related to the impacts of the COVID-19 pandemic. Based on this understanding, a methodological framework was designed to bridge the gap between prosody teaching goals and digital tools. At the next stage, experimental teaching was conducted to evaluate the feasibility of this framework. Once data from the interviews, rating scales and participant observation were collected, a descriptive analysis of the results was given. The findings showed that the suggested training had an important effect on L2 prosody acquisition by engineering students.
\end{abstract}

Key words: CAPT, prosodic competence, engineering discourse, crisis distance teaching

\section{Introduction}

The unprecedented shift to online teaching during the pandemic put tertiary-level L2 spoken communication courses into an unfavorable position. As crisis remote teaching unfolded, we have seen the global disruption of pre-existing curriculum resulted in the reinvention of educational practices aimed at minimizing the learning losses and dropouts. Being one of the most difficult skills to master (Fouz-Gonzalez, 2015: 314) pronunciation teaching was exposed to particular risks. Before the pandemic, pronunciation was often approached in an ad-hoc manner when teachers focused only on communicative mistakes interfering with understanding (Ding et al., 2019: 51). As Levis (2007: 196) states, pronunciation lost in the struggle with high priority language skills lying at the heart of the communicative approach. In addition to the loss of value, teacher's lack of experience and confidence had the effect of depriving learners of one of the most critical skills for effective oral communication (Baker, 2011; Baker, 2014; Macdonald, 2002; Murphy, 2014; Couper, 2018; O'Brien et al., 2019; Hodgetts, 2020). All in all, the peripheral status of pronunciation teaching (Baker, 2013; Derwing, Munro, 2009) has contributed to significant learning losses long before the largest disruption of education systems (Derwing et al., 2012). It has become evident that prosody teaching, viewed by many as "peripheral frills" (Avery \& Ehrlich, 2012: 185), seems to have relatively low chances to make its way into an e-learning emergency curriculum.

The ongoing crisis has incentivized technological innovation and alternative modes of delivery in education systems (UN, 2020: 2). One of the ways to address the abovementioned issues might be the use of CAPT programs. In recent decades, researchers have provided solid evidence of CAPT efficiency in individualizing and maximizing training (Levis, 2007; Hincks, 2015). Despite this progress, digital tools were usually seen as supplementary flashy "cool tools" while the bulk of teaching took place in a face-to-face course. Nowadays the priority of emergency remote learning is the search 
for the active approaches enhancing "practice, reflection, peer-to-peer learning and collaboration, and contextualizing its application to real-world problems" (UNICEF, 2020: 12). Although there is a great number of diverse CAPT software to date, their potential to respond to immediate learning challenges is yet to be scrutinized by practitioners.

The goal of this section is to provide a critical overview of the current state of CAPT and digital tools for L2 prosody training, evaluate their appropriateness in terms of crisis distance teaching and present the results of using CAPT during remote L2 prosody teaching to Russian engineering students as part of the course on Speaking for Academic Purposes.

\section{Literature review}

Technological advances of the recent decades have made it possible to reimagine pronunciation teaching through the extensive use of CAPT programs and applications. More than any other language practice, pronunciation activities must be designed to appeal to visual, auditory and kinesthetic learner modes (Celce-Murcia, 1996: 316). It was the properties of CAPT that allowed to realize the potential of multimodality and variety to the full extent (Pennington, Rogerson-Revell, 2018: 274).

There exist at least three approaches to determining the basic teaching principles that CAPT designers should consider. In 1999, Pennington (2018: 239) suggested five principles for developing CAPT materials. They are the use of baseline accents, objectivity (measurable goals), achievability (from easier to more challenging tasks), communicative relevance and learner awareness. Based on his years of using CAPT, Levis (2007: 192-193) brought forward an idea that to be feasible CAPT should rely on the principles of consistency with human feedback, immediacy, pertinence, affordability, individualization, control and correction. The CAPT principles proposed by Fouz-Gonzalez (2015: 333) include learner autonomy, achievability, individualization and contextualization. It is apparent that, despite certain variations, the authors are unanimous in emphasizing the ability of an ideal CAPT to consider various contexts and learner's needs. In this respect, CAPT technologies represent an ideal solution to the urgent need for flexible and quasi-individualized learning pathways (UN, 2020: 25).

At the same time, the attractiveness of e-learning pronunciation tools is overshadowed by serious disadvantages and controversies. For the last several years we have seen that initial enthusiasm of researchers about CAPT gave way to disillusionment. In 2007, Levis (2007: 186) claimed that CAPT "remains in its infancy". A decade later he stated that CAPT still had many "structural weaknesses" (Levis, 2018: 178). The most critical issue with CAPT is its inconsistency with pedagogical aims and lack of strong theoretical foundation (Levis, 2007: 186; Fouz-Gonzalez, 2015: 330; Pennington \& Rogerson-Revell, 2018: 238; Yoshida, 2018: 195). In particular, most CAPT systems are still native accent-centered rather than intelligibility-based (Pennington \& Rogerson-Revell, 2018: 269) and inappropriate for teaching within communicative methodologies (Hincks, 2015: 506). In the current circumstances of potential learning losses and the increased value of monitoring, assessment and statistics (UNICEF, 2020: 12; UN, 2020: 12), the gap between practice and learning goals can discourage teachers from online pronunciation practice.

Concerning teaching suprasegmental phonetics, there are not so many CAPT technologies compared to those designed to training segmentals. One of the most promising CAPT approaches to master L2 prosody is a visual representation of pitch, duration and loudness of the speech signal on a screen (Celce-Murcia, 1996; Pennington \& Rogerson-Revell, 2018; Hodgetts, 2020). Such programs as Praat, Speech Analyzer, Audacity, etc., allow learners to receive immediate feedback, compare their intonation contour with a model one and see the connection between

XLinguae, Volume 14 Issue 1, January 2021, ISSN 1337-8384, eISSN 2453-711X 
the prosodic and syntactical levels. There is extensive research proving the efficiency of visual representation in teaching L2 prosody (Levis, Pickering, 2004; Hardison, 2005; Wilson, 2008; Hincks, Edlund, 2009; Gorijan et al., 2013; Vincela, 2019). The analysis of the visual feedback and subsequent corrective modification of speech empowered learners to improve their perceptual and production skills. Nevertheless, the need for expert knowledge to interpret acoustic data and lack of transparency for a student constitute a serious limitation in using visual representations for autonomous practice during remote crisis teaching (Levis, 2007: 191; Compton: 2009; FouzGonzalez, 2015: 327; Yoshida, 2018: 208).

With the demand to minimize the digital divide and stimulate mobility, mobileassisted language learning (MALL) has come to the forefront of emergency teaching. Educators were required to master MALL both in teaching and assessment (UNICEF, 2020: 12). Although a wide range of accent reduction, speech synthesis and visualization apps are available on the market (Foote, Medonough, 2017: 37), the amount of activities they offer is limited (Fouz-Gonzales, 2015: 332). The greatest benefits of MALL technologies for pronunciation instruction include ubiquity, affordability, convenience, intuitive appeal and gamelike appearance (Golonka et al., 2012: 84; Fouz-Gonzales, 2015: 332; Pennington \& Rogerson-Revell, 2018: 250). However, controversy arises when it is claimed that m-learning technologies were not sufficiently addressed during the crisis distance teaching. According to the survey conducted by UNICEF in 133 countries, student-teacher interactions using mobile phones and social networks were rare, unsystematic, and lacking feedback (UNICEF, 2020, 7). The reason behind this discouraging result is the lack of research on the use of social networking for language learning (Golonka et al., 2012:84) and the educators' disregard for young people's digital practices.

It was shown that so far CAPT can not offer an affordable, readily available and pedagogially-driven tool encompassing all the principles of CAPT design. In response to the mentioned challenges and limitations, it is recommended not to view CAPT as a "silver bullet" for building a supportive learning environment. Nor should it be approached as a goal in itself. When choosing an effective pronunciation technology, teachers should primarily consider the pedagogical aims and learners' needs (Yoshida, 2018: 195) to enable robust learning and effective instruction to meet the needs of the time.

\section{Methodology}

In this study, we focus on the impacts of using a combination of technologies aimed at preparing higher education students to effective nonverbal interaction at workplace. Practicing English prosody was integrated with the course on Academic Speaking and assessed as one of the prerequisites to successful interacting with the public when reporting research results. The choice of CAPT options was underpinned by the principles of individualization, contextualization, communicative relevance, learner awareness, learner autonomy, achievability and differentiation. The teaching period lasted for 3 months, starting with a pre-teaching interview followed by guided instruction. The limitations during this research were 1) a fully online course with inevitable sound distortions and connection dropouts 2) the absence of a control group, 3 ) focus on the prosody of engineering discourse.

\section{Participants}

The participants were forty Russian-speaking learners of English majoring in engineering. The learners had B2/C1 level of English language competence and studied at undergraduate and graduate levels at Moscow Institute of Physics and Technology. Raters included 1 non-native English-speaking teacher with extensive experience in pronunciation teaching and rating. 


\section{Materials}

Materials used in this study included prerecorded YouTube videos of presenting engineers to conduct a pre-teaching learner survey, audio recordings of read-aloud tasks, recordings of learners' technical presentations, and audio recordings of pre-, mid-, and post-teaching interviews.

\section{Procedure}

It should be noted that the suggested procedure is not innovative and can be found among the most robust ways to teach suprasegmentals (Yoshida, 2018; 197; Hodgetts, 2020). Though there is always a place for innovations in a classroom, the challenging times require to opt for resilient teaching practices.

At the pre-teaching stage, students were exposed to model and antimodel presentations, delivered by native-English-speaking (NS) and non-native-Englishspeaking (NNS) engineers. To introduce the learning goals implicitly, students were asked to evaluate the presenters delivery skills in a Google survey, accompanied by a video readily available on YouTube. The survey results were shared with the students in a social network to discuss the good and bad points of the presenters' prosodic skills. Through this group reflective practice students noticed the critical value of prosodic features which incentivized them to build up their prosodic competence.

At the mid-teaching stage, we introduced some instructional intervention related to the use of prosodic cues typical for an informative (intermediate level) and a persuading (advanced level) speech.

The post-teaching stage involved an independent task simulating a professional communicative situation - reporting research results to the public with the use of appropriate L2 prosodic patterns.

The core CAPT technology for providing feedback was a digital portfolio, defined as a dynamic repository of learning artefacts stimulating metacognitive strategies, such as analysis and reflective thinking (Rhodes, 2011; Ciesielkiewicz, 2012; Yesenina, 2019). The portfolio was managed by the teacher who uploaded the students' recordings to her Youtube channel. The learning results were discussed during a video conference session, using break out rooms. The order of sharing can be planned in advance. As an alternative, teacher or peer feedback can be submitted to a chatbox of a social network in an audio or video format. The CAPT-based methodological framework designed for this study is presented in Table 1. 
Table 1: CAPT-based framework designed for developing $\mathrm{L2}$ prosodic competence for workplace communication

\begin{tabular}{|c|c|c|c|c|}
\hline Stage & Automonay & Activity & Goal & Technology \\
\hline \multirow{2}{*}{ 量 } & \multirow{2}{*}{ 总 } & $\begin{array}{l}\text { Initial } \\
\text { diaznosis } \\
\text { Providing } \\
\text { pronunciation } \\
\text { models }\end{array}$ & \multirow{2}{*}{ 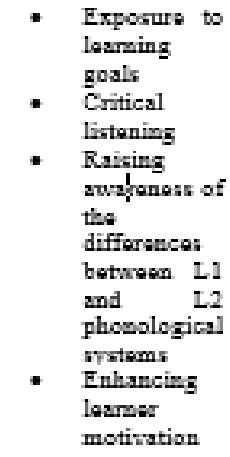 } & $\begin{array}{l}\text { - Google survey with } \\
\text { embedded } \\
\text { prerecorded } \\
\text { YouTube videos } \\
\text { - E-portfolio }\end{array}$ \\
\hline & & Interviens & & $\begin{array}{l}\text { - Video confarencing } \\
\text { platform } \\
\text { - SNS for shuring } \\
\text { loarner survey rovults }\end{array}$ \\
\hline \multirow{3}{*}{ 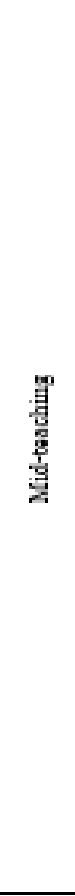 } & \multirow{3}{*}{ 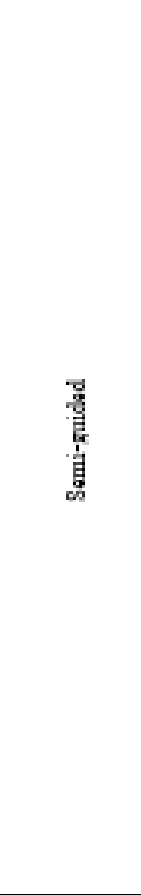 } & $\begin{array}{l}\text { Critical } \\
\text { listeming }\end{array}$ & $\begin{array}{l}\text { Deroloping } \\
\text { perception skills } \\
\text { (noticing. } \\
\text { discrimination) }\end{array}$ & $\begin{array}{l}\text { - Resdy-to-use audio } \\
\text { nd video recordings } \\
\text { to offer lesmers a } \\
\text { ramge of appropriate } \\
\text { target models of NS } \\
\text { discourse }\end{array}$ \\
\hline & & $\begin{array}{l}\text { Reod-aloud } \\
\text { tasks } \\
\text { (santence } \\
\text { leveI) }\end{array}$ & $\begin{array}{l}\text { Deroloping } \\
\text { production skills } \\
\text { (mitation) }\end{array}$ & $\begin{array}{l}\text { - Video conforencing } \\
\text { platform } \\
\text { - Nobile apps for } \\
\text { visualiring prosodic } \\
\text { festures } \\
\text { Self-recording using } \\
\text { a mobile dictation } \\
\text { app } \\
\text { SNS for sharing the } \\
\text { adio flles, peer- } \\
\text { rerriew and } \\
\text { corrective foedback }\end{array}$ \\
\hline & & $\begin{array}{l}\text { Resding } \\
\text { aloud of an } \\
\text { extract from } \\
\text { a technical } \\
\text { prosantation } \\
\text { Observing L2 } \\
\text { prosodie } \\
\text { patterns } \\
\text { typieal for a } \\
\text { teclunical } \\
\text { prosentation }\end{array}$ & $\begin{array}{l}\text { Mid-course } \\
\text { assessment: } \\
\text { corrective } \\
\text { foedback, self and } \\
\text { pear assessment, } \\
\text { reflectiro practice }\end{array}$ & $\begin{array}{l}\text { - Video conforencing } \\
\text { platform } \\
\text { Self-recording using } \\
\text { a mobile dictation } \\
\text { app } \\
\text { SNS for skarimg the } \\
\text { avdio flles } \\
\text { - E-portfolio }\end{array}$ \\
\hline 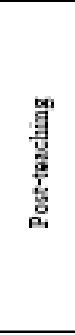 & 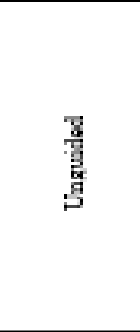 & $\begin{array}{l}\text { Doliver a } \\
\text { technical } \\
\text { prosantation } \\
\text { observing L2 } \\
\text { prosodic } \\
\text { patterns } \\
\text { typīeal for } \\
\text { both an } \\
\text { informative } \\
\text { and } \\
\text { couvincing } \\
\text { speach }\end{array}$ & $\begin{array}{l}\text { End-of-courve } \\
\text { assescment: } \\
\text { cocrective } \\
\text { foedback, self and } \\
\text { peer assossment, } \\
\text { reflectivo practice }\end{array}$ & $\begin{array}{l}\text { - Video conforencing } \\
\text { platform } \\
\text { - Self-recording using } \\
\text { a mobile phome or a } \\
\text { laptop } \\
\text { - SNS for skaring the } \\
\text { video files, fesdback } \\
\text { - E-portfolio }\end{array}$ \\
\hline
\end{tabular}




\section{Results and Discussion}

Results revealed the significant effect of using CAPT-based framework on L2 prosodic competence of Russian-speaking technical students. The analysis of students' pre-teaching evaluations showed that they were able to identify the pronunciation model among both NS and NNS presenters. The points of the survey (1-7) in Figure 1 are the key elements of a public speech where prosodic skills contribute most. We deliberately provided a pronunciation antimodel presented by a NS to underscore the decreased priority of accent in getting one's communicative intention across in a foreign language, unless it is intelligible.

With a reference model and learning goals in mind, students could evaluate their own prerecorded presentations (E-portfolio, pre-teaching stage) in a much more productive way. The use of Google services had a positive impact on data collection and interpretation.

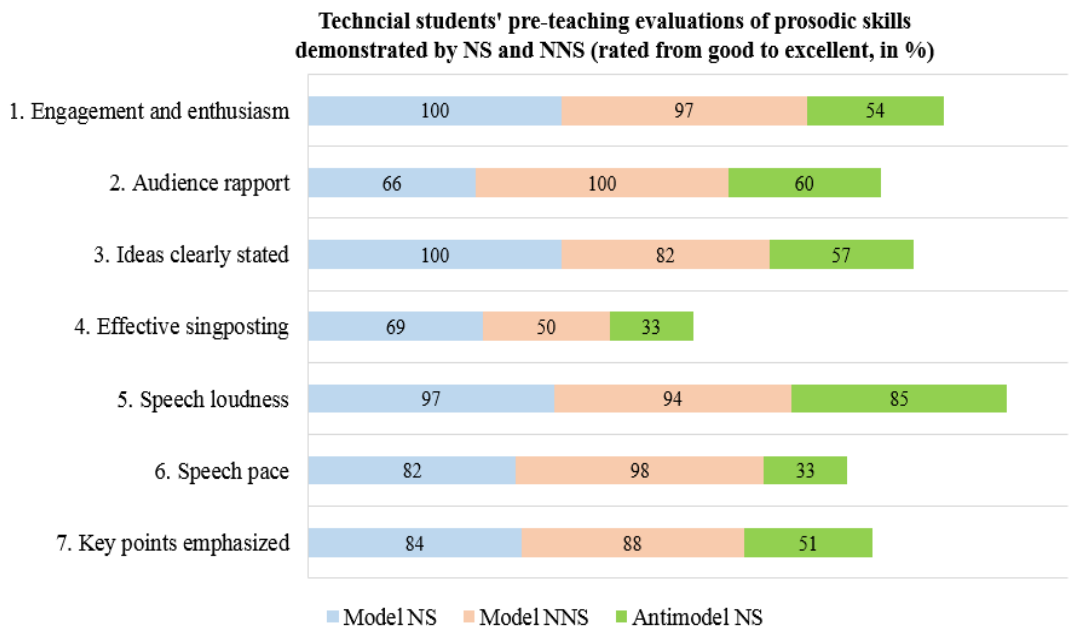

\section{Figure 1: Technical student's judgements of NS and NNS engineers' prosodic competence based on Google survey}

During the course, we judged the students' progress with the help of a digital portfolio, which proved to be a flexible assessment tool. The opportunity to track progress continuously with permanent access to speech samples enabled students to replay and review their results without the limitations of a traditional classroom (Challis, 2005; Chang et al., 2013; Yastibas, Yastibas, 2015). Difficulties may arise, however, with the increase of teacher's workload connected with uploading numerous videos (Slepcevic-Zach, Stock, 2018). A student-managed portfolio might be a much less time-consuming option (Dyson et al., 2018: 107).

Since no CAPT programs support valid automated feedback on discourse prosody available on the market (Levis, 2007: 193; Golonka et al., 2012: 82; Hincks, 2015: 516; Pennington, Rogerson-Revell, 2018: 248; Levis, Suvorov, 2020: 152), we relied on a specially designed listener-based rating scale. This empirical method is known to be suitable for intelligibility and performance assessment (Munro, Derwing, 1995: 77; Isaacs, Thomson, 2013: 137; Pennington, Rogerson-Revell, 2018: 290; Kang, Ginther, 2017: 37; Kang, Thomson, Moran, 2018: 118).

According to Figure 2, during the mid-course assessment, there was a 50\%, almost 4 times increase in the number of learners achieving the intermediate level related to the

XLinguae, Volume 14 Issue 1, January 2021, ISSN 1337-8384, eISSN 2453-711X 
use of prosodic cues typical for an informative public speech. The post-teaching assessment showed that CAPT-based activities had a lasting impact as evidenced by the number of learners with positive sustainable results $(90 \%)$.

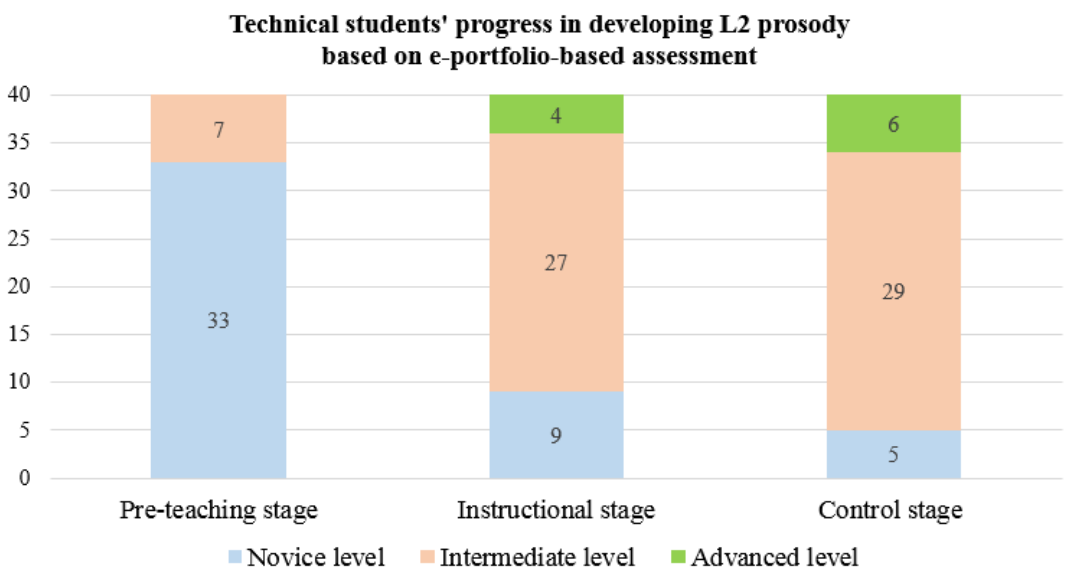

\section{Figure 2: E-portfolio-based assessment of technical students' progress in mastering $\mathrm{L} 2$ prosody for workplace communication}

While observing the learners' reactions during the Zoom interviews we noticed a positive trend in developing self-efficacy. This was facilitated by changing their mind about previously overlooked issues of professional communication (Kisicek, 2008: 345; Kudesia, Elfenbein, 2013: 806; Patel, Scherer, 2013: 196), building up confidence in using online tools when acquiring a rather complex set of skills (Hirschberg, 2002) in emergency remote teaching, and moving from guided instruction to the autonomous work.

The study provides additional support for the assumption that teachers should opt for the technologies appropriate to learning objectives (Golonka et al., 2012: 93; O'Brien et al., 2019: 200), "not necessarily those that seem newest, coolest, or flashiest" (Yoshida, 2018: 208). Among the limitations of this study, we can call the absence of a control group and data collected from other technical institutions. Future directions of the research are to adapt the suggested framework to teaching other aspects of prosody and explore the emerging technologies from the viewpoint of their applicability to solving urgent educational problems.

\section{Conclusions}

In this study, we looked at the potential of implementing CAPT for L2 prosodic acquisition by tertiary level learners to respond to the shocks to education systems caused by the pandemic. The major challenge consisted of aligning the remote learning content with the curriculum. The situation was exacerbated by the specifics of pronunciation teaching as one of the aspects most dependent on face-to-face interaction. The critical analysis of available CAPT technologies indicated at the mismatch between the computer-aided forms of teaching and pedagogical principles. The risks of learning losses conditioned the search for a pedagogically-driven and resilient CAPT-based learning approach. The suggested framework embraced both the core principles of CAPT systems and prosody teaching (individualization, contextualization, communicative relevance, learner awareness, learner autonomy, 
achievability and differentiation). A particular focus was placed on the use of mobile technologies and social networks as an unavoidable part of learners' e-routine. The results of the 3-month training proved the efficiency of the proposed approach empowering students to achieve the set goals. Our findings have important practical implications. The study has gone some way to rebut the skeptical arguments against the possibility of teaching suprasegmentals in online settings. We have devised an approach that could help minimize the learning losses in terms of L2 prosody acquisition by means of pedagogically useful, practical and freely available tools. We hope that our research will be valuable for those who express discomfort with new technologies in developing nonverbal communication skills at a tertiary level. The proposed strategy has the potential, at least to a certain degree, to be transferred to other aspects of language teaching in order to sustain seamless learning continuity.

\section{Bibliographic references}

AVERY, P. - EHRLICH, S. L. 2012. Teaching American English pronunciation. Oxford: Oxford University Press. ISBN 0194328155.

BAKER, A. 2011. Discourse prosody and teachers' stated beliefs and practices. In: TESOL Journal, vol. 2, n. 3, pp. 263-292. ISSN 1949-3533.

BAKER, A. 2013. Integrating fluent pronunciation use into content-based ESL instruction: Two case studies. In: J. Levis, \& K. LeVelle (Eds.), Proceedings of the 4th pronunciation in second language learning and teaching conference, pp. 245-254. Ames, IA: Iowa State University. ISSN 2215-1931.

BAKER, A. 2014. Exploring teachers' knowledge of second language pronunciation techniques: Teacher cognitions, observed classroom practices, and student perceptions. In: TESOL Quarterly, vol. 48, n. 1, pp. 136-163. ISSN 1545-7249.

CELCE-MURCIA, M. 1996. Teaching pronunciation. Cambridge: Cambridge University Press. ISBN: 9780521406949.

CHALLIS, D. 2005. Towards the mature ePortfolio: Some implications for higher education. In: Canadian Journal of Learning and Technology, vol. 31, n. 3, ISSN 14996677.

CHANG, C-C. - TSENG, K-H. - LIANG, C. - CHEN, T-Y. 2013. Using eportfolios to facilitate university students' knowledge management performance: Eportfolio vs. non-portfolio. In: Computers and education, vol. 69, pp. 216-224. ISSN 0360-1315.

CIESIELKIEWICZ, M. 2012. Digital humanities: the electronic language portfolio as a tool for instruction and evaluation. In: 1st Annual International Conference on Language, Literature \& Linguistics (L3 2012), pp. 109-112. ISSN 2251-3566.

COMPTON, L. K. L. 2009. Preparing language teachers to teach language online: a look at skills, roles, and responsibilities. In: Computer Assisted Language Learning, vol. 22, n. 1, pp. 73-99. ISSN 0958-822.

COUPER, G. 2016. Teacher Cognition of Pronunciation Teaching: Teachers' Concerns and Issues. In: TESOL Quarterly, vol. 51, n. 4, pp. 820-843. ISSN 15457249.

DERWING, T. - MUNRO, M. J. 2009. Putting accent in its place: Rethinking obstacles to communication. In: Language Teaching, vol. 42, n. 4, pp. 476-490. ISSN 0261-4448.

DERWING, T. M. - DIEPENBROEK, L. G. - FOOTE, J. A. 2013. How Well do General-Skills ESL Textbooks Address Pronunciation? In: TESL Canada Journal, vol. 30, n. 1, pp. 22-44. ISSN 0826-435X.

DING, S. - LIBERATORE, C. - SONSAAT, S. - LUCIC, I. - SILPACHAI, A. ZHAO, G. - GUTIERREZ-OSUNA, R. 2019. Golden speaker builder - an interactive tool for pronunciation training. In: Speech Communication, vol. 115, pp. 51-66. ISSN 0167-6393.

XLinguae, Volume 14 Issue 1, January 2021, ISSN 1337-8384, eISSN 2453-711X 
DYSON, M. - PLUNKETT, M. - MCCLUSKEY, K. 2018. Success in Professional Experience: Building Relationships in Educational Settings. Cambridge: Cambridge University Press. ISBN 9781316091982.

UN POLICY BRIEF: EDUCATION DURING COVID-19 AND BEYOND. 2020.

Retrieved September 27, 2020, Available online:

https://www.un.org/development/desa/dspd/wp-

content/uploads/sites/22/2020/08/sg_policy_brief_covid-

19_and_education_august_2020.pdf

FOOTE, J. A. - MCDONOUGH, K. 2017. Using shadowing with mobile technology to improve L2 pronunciation. In: Journal of Second Language Pronunciation, vol. 3, n. 1, pp. 34-56. ISSN 2215-1931.

FOUZ-GONZALEZ, J. 2015. Trends and directions in computer-assisted pronunciation training. Investigating English Pronunciation, pp. 314-342. ISBN 9781-137-50943-7.

FOUZ-GONZALEZ, J. 2020. Using apps for pronunciation training: an empirical evaluation of the English file pronunciation app. In: Language Learning \& Technology, vol. 24, n. 1, pp. 62-85. ISSN 1094-3501.

GOLONKA, E. M. - BOWLES, A. R. - FRANK, V. M. - RICHARDSON, D. L. FREYNIK, S. 2012. Technologies for foreign language learning: A review of technology types and their effectiveness. In: Computer Assisted Language Learning, vol. 27, n. 1, pp. 70-105. ISSN 0958-8221.

GORJIAN, B. - HAYATI, A. - POURKHONI, P. 2013. Using Praat software in teaching prosodic features to EFL learners. In: Procedia - Social and Behavioral Sciences, vol. 84, pp. 34-40. ISSN 1877-0428.

HARDISON, D. M. 2004. Generalization of computer assisted prosody training: quantitative and qualitative findings. In: Language Learning \& Technology, vol. 8, n. 1, pp. 34-52. ISSN 1094-3501.

HINCKS R. - EDLUND J. 2009. Promoting increased pitch variation in oral presentations with transient visual feedback. In: Language learning \& technology, vol. 13, n. 3, pp. 32-50.

HINCKS, R. 2015. Technology and learning pronunciation. The Handbook of English Pronunciation. Edited by Marnie Reed and John M. Levis. John Wiley \& Sons, Inc. ISBN 9781118314470.

HIRSCHBERG, J. 2002. Communication and prosody: Functional aspects of prosody. In: Speech Communication, vol. 36, n. 1-2, pp. 31-43. ISSN 01676393.

HODGETTS, J. 2020. Pronunciation instruction in English for Academic Purposes: an investigation of attitudes, beliefs and practices. Springer Nature. ISBN 978-3-03056-116-1.

ISAACS, T. - THOMSON, R. I. 2013. Rater Experience, Rating Scale Length, and Judgments of L2 Pronunciation: Revisiting Research Conventions. In: Language Assessment Quarterly, vol. 10, n. 2, pp. 135-159. ISSN 1543-4303.

KANG, O. - GINTHER, A. 2018. Assessment in Second Language Pronunciation. London and New York: Routledge. ISBN 978-1-138-85687-5.

KANG, O. - THOMSON, R. - MORAN W.M. 2018. Empirical Approaches to Measuring the Intelligibility of Different Varieties of English in Predicting Listener Comprehension. In: Language Learning, vol. 68, n. 1, pp. 115-146. ISSN: 0023-8333.

KISICEK, G. 2018. Persuasive power of prosodic features. In: Argumentation and Advocacy, vol. 54, n. 4, pp. 345-350. ISSN 0002-8533.

KUDESIA, R. S. - ELFENBEIN, H. A. 2013. Non-Verbal Communication in the Workplace. In: Nonverbal Communication, Mouton de Gruyter. pp. 805-832, ISBN 978-3-11-023815-0.

LEVIS, J. M. 2007. Computer technology in teaching and researching pronunciation. In: Annual review of applied linguistics, vol. 27. ISSN 0267-1905/08. 
LEVIS, J. 2018. Technology and second language pronunciation. In: Journal of Second Language Pronunciation, vol. 4, n. 2, pp. 173-181. ISSN 2215-1931.

LEVIS, J. - PICKERING, L. 2004. Teaching intonation in discourse using speech visualization technology. In: System, vol. 32, n. 4, pp. 505-524. ISSN 0346-251X.

LEVIS, J. - SUVOROV, R. 2020. Automatic speech recognition. In: C. A. Chapelle (Ed.), The Concise Encyclopedia of Applied Linguistics. New York, NY: WileyBlackwell. ISBN: 978-1-119-14736-7.

LUO, B. 2014. Evaluating a computer-assisted pronunciation training (CAPT) technique for efficient classroom instruction. In: Computer Assisted Language Learning, vol. 29, n. 3, pp. 451-476. ISSN 0958-8221.

MACDONALD, S. 2002. Pronunciation views and practices of reluctant teachers. In: Prospect: An Australian Journal of TESOL, vol. 17, n. 3, pp. 3-18, ISSN 0814-7094.

MUNRO, M. J. - DERWING, T. M. 1995. Foreign Accent, Comprehensibility, and Intelligibility in the Speech of Second Language Learners. In: Language Learning, vol. 45, n. 1, pp. 73-97. ISSN: 0023-8333.

MURPHY, J. 2014. Myth 7: Teacher training programs provide adequate preparation in how to teach pronunciation. In: L. Grant (Ed.), Pronunciation myths: Applying second language research to classroom teaching, Ann Arbor: University of Michigan Press. pp. 188-224, ISBN 9780472035168.

O'BRIEN, M.M. - DERWING, T.M. - CUCCHIARINI, C. - HARDISON, D.M. MIXDORFF, H. - THOMSON, R.I. - STRIK, H. - FOOTE, J.A. - LEVIS, J.M. MUNRO, M.J. - LEVIS, G.M. 2019. Directions for the future of technology in pronunciation research and teaching. In: Journal of Second Language Pronunciation, vol. 4, n. 2, pp. 182-206. ISSN 2215-1931.

PATEL, S. - SCHERER, K. 2013. Vocal behavior. In: Nonverbal Communication (pp. 167-203). Mouton de Gruyter. ISBN 978-3-11-023815-0.

PAULSON, F. - PAULSON, P. - MEYER, C. 1991. What makes a portfolio a portfolio? In: Educational Leadership, vol. 58, n. 5, pp. 60-63. ISSN 0013-1784.

PENNINGTON, M. C. - ROGERSON-REVELL, P. 2018. Using technology for pronunciation teaching, learning, and assessment. In: English Pronunciation Teaching and Research. Palgrave Macmillan. ISBN 978-1-137-47677-7.

PUTTING THE 'LEARNING' BACK IN REMOTE LEARNING. UNICEF. 2020.

Retrieved September 27, 2020, Available online: https://www.unicef.org/globalinsight/sites/unicef.org. globalinsight/files/202006/UNICEF-Global-Insight-remote-learning-issue-brief-2020.pdf

RHODES, T. L. 2010. Making Learning Visible and Meaningful Through Electronic Portfolios. In: Change: The Magazine of Higher Learning, vol. 43, n. 1, pp. 6-13. ISSN 0009-1383.

SLEPCEVIC-ZACH, P. - STOCK, M. 2018. ePortfolio as a tool for reflection and self-reflection. In: Reflective Practice, vol. 19, n. 3, pp. 291-307. ISSN 1462-3943.

VINCELA, Z. 2019. Visualisation Of VOT variations in teaching English pronunciation at tertiary level. In: INTED2019 Proceedings, pp. 4996-5001. ISSN 2340-1079.

WILSON I. 2008. Using Praat and Moodle for teaching segmental and suprasegmental pronunciation. In: Proceedings of the 3rd International WorldCALL Conference: Using Technologies for Language Learning, pp.112-115. ISBN 978-4990-48-07-0-7.

YASTIBAS, A. E. - YASTIBAS, G. C. 2015. The Use of E-portfolio-based Assessment to Develop Students' Self-regulated Learning in English Language Teaching. In: Procedia - Social and Behavioral Sciences, vol. 176, pp. 3-13. ISSN 1877-0428.

XLinguae, Volume 14 Issue 1, January 2021, ISSN 1337-8384, eISSN 2453-711X 
YOSHIDA, M. T. 2018. Choosing technology tools to meet pronunciation teaching and learning goals. In: CATESOL Journal, vol. 30, n. 1, pp. 195-212. ISSN 2215193.

YESENINA, N. 2019. Electronic language portfolio for foreign language training in engineering universities. In: ICERI2019 Proceedings, pp. 10744-10751. ISSN 23401095.

Words: 4249

Characters: 29754 (16,53 standard pages)

Assoc. Prof. Tatiana Aleksandrovna Polushkina, $\mathrm{PhD}$

Department of Foreign Languages

Moscow Institute of Physics and Technology (National Research University)

9 Institutskiy lane.

141701 Dolgoprudny, Moscow region

Russian Federation

polushkina.ta@mipt.ru

Prof. Elena Genrikhovna Tareva, Dr.Sc.,

Institute of Foreign Languages

Moscow City University

5 b Maly Kazenny per.

105064 Moscow

Russian Federation

TarevaEG@mgpu.ru 